\author{
V.P. Mylnikov \\ Institute of Archaeology and Ethnography, \\ Siberian Branch, Russian Academy of Sciences, \\ Pr. Akademika Lavrentieva 17, Novosibirsk, 630090, Russia \\ E-mail:mylnikov@archaeology.nsc.ru
}

\title{
Early Iron Age Carpenter Tools from the Altai and Adjacent Territories
}

This article deals with the functional attribution of Early Iron Age woodworking tools from the Altai and adjacent areas. Finds come from burials, settlements, and hoards; some are random. The attribution was based on the analysis of traces left by tools on the surfaces of wooden items. The methods were both traditional and special (use-wear, typological, and experimental), enabling one to reconstruct the function of the tool, manufacturing technique, organization of the manufacturing process, technology, and, to some extent, skill. The totality of data suggests that tools were of several types: metal ones used for chopping (celts, axes, and adzes), wooden ones used for striking (hammers, mallets, and mauls), universal cutting and shaving tools (knives of various sizes and profiles), striking and cutting combined tools (chisels), cutting and boring tools (flat drills, reamers, and awls). Results of use-wear analysis in terms of operations (chopping, shaving, and cleavage) suggest that since the Early Bronze Age, three types of processing surfaces with chopping tools have been used: butting, cutting with the grain, and cutting across the grain. Factors affecting efficiency and accuracy of woodworking are discussed.

Keywords: Early Iron Age, Altai, woodworking tools, tool attribution.

\section{Introduction}

An idea of the methods of manufacturing wooden items and woodworking as an established set or system of sequential actions in the Early Iron Age in the Altai and adjacent territories can be ascertained using the results of comprehensive analysis of all the wooden artifacts, as well as the stone and metal tools with which these artifacts were made. Very few sources from that time have survived. All the wooden artifacts of the Early Iron Age were mostly found at the sites containing permafrost formations. Tools for wood processing were mainly from surface finds and a part of hoards; therefore, they can be connected with a specific time and place only hypothetically.

Primary traces of processing by the blades of tools used by ancient carpenters and wood carvers have survived on the external and internal surfaces of wooden items extracted from the permafrost sites. Use-wear analysis and comparative typological analysis of these items, together with tools from hoards and surface finds, has made it possible to reconstruct the approximate sizes and shapes of working edges, tool blades, as well as techniques and methods of working with them, and distinguish the types of wood processing in the Early Iron Age.

The vast majority of wooden artifacts with traces of processing are finds from the sites of the Late Bronze Age and Early Iron Age (Mylnikov, 2003, 2008; Mylnikov, Bobrov, 2011). Use-wear analysis and comparativetypological research of marks left by various tools and the peculiarities of wooden surface processing indicate the emergence of the main set of woodworking tools at that time. These tools were made of high-quality

Archaeology, Ethnology \& Anthropology of Eurasia 48/1 (2020) 110-119 E-mail: Eurasia@archaeology.nsc.ru (C) 2020 Siberian Branch of the Russian Academy of Sciences

(C) 2020 Institute of Archaeology and Ethnography of the Siberian Branch of the Russian Academy of Sciences (C) 2020 V.P. Mylnikov 
materials that were new for the artisans-bronze and iron. Manufacturing techniques and methods were also improved. It can be assumed that it was exactly in that period that the most important woodworking traditions for this region or culture were elaborated. Owing to large amount of woodwork, labor cooperation intensified, and great opportunities for the development of artisanal forms of production appeared.

Raw materials, processing tools, and a person (a woodworking specialist) form the totality of primary means needed for organizing the production of an artifact - this is a single whole comprising any ancient production process. Each of its components has its own features, which in combination give us clear idea about the emergence of a finished product.

\section{Research methods and materials}

A well-ordered system of stages and operations for changing wooden blanks by using all types of tools with cutting edges constitutes the process of wood processing by cutting (Borisov, 1999: 63). In the Early Iron Age, wood processing included several stages; each of them entailed its own set of operations (Fig. 1). Each stage and operation required the use of a specific tool.

The earliest sets of tools for primary and secondary wood processing occur among lithic artifacts from the Neolithic settlements of the Urals. Preparatory or primary wood processing was carried out using axes, chisels, sidescrapers, or saws (blades with notched edges).

A set of tools "for producing finishing and engraving works" (i.e. for secondary finishing) consisted of planes, shaving knives, drills, reamers, cutters, and burins
(Usacheva, 1997). The variety of Neolithic stone tools indicates a high level of woodworking, and makes it possible to reconstruct the technology of secondary surface treatment of artifacts and the standard order of main operations in this cycle: rough shaving, scrapingevening, finish planing, carving and engraving, smoothing and polishing (Mylnikov, 2003).

The reconstruction of specific techniques and elements of wood processing in the Early Iron Age is complicated by the fact that the tools of that time have usually been random surface finds or parts of hoards, not associated with cultures (Akishev A.K., 1984: 10; Morgunova, 1994: 167; Mylnikov, 2003; Akishev K.A., Kushaev, 1963: 106-110; Popescu, Antonini, Baipakov, 1998: 262, fig. 389-396). According to E.N. Chernykh, in ancient times, the artisans took great care of their tools; they kept even broken and worn-out tools in fear that "these might deprive them [their owners translator's note] of their skills and power, and send diseases to the whole family clan for disrespecting them" (1972: 196).

In the absence of tools, information about them can be found from their traces on wooden artifacts (Fig. 2, 3). Comparing such marks on archaeological artifacts, experimental samples, and ethnographic items makes it possible to reconstruct the appearance of tools: their shape, width, and the thickness of the working edge, configuration of blade profile, degree of sharpness, and angle of sharpening (Raev, 1976). Information on the location and nature of the marks left by tools, the depth of the marks, and the direction of blade's movement constitute the basis for reconstructing methods and techniques for using this tool, as well as technological operations (Mylnikov, 1999, 2008).

\begin{tabular}{|c|c|c|}
\hline \multicolumn{3}{|c|}{ STAGES } \\
\hline WOOD SELECTION & $\begin{array}{l}\text { WOOD PREPARATION } \\
\text { FOR PROCESSING }\end{array}$ & $\begin{array}{c}\text { WOOD PROCESSING } \\
\text { (PRODUCTION OF AN ITEM) }\end{array}$ \\
\hline \multicolumn{3}{|c|}{ OPERATIONS } \\
\hline$\nabla$ & $\checkmark$ & $\checkmark$ \\
\hline $\begin{array}{l}\text { Selection of wood type } \\
\text { Logging } \\
\text { Removal of branches } \\
\text { Removal of bark } \\
\text { Drying }\end{array}$ & $\begin{array}{l}\text { Ripping } \\
\text { Splitting } \\
\text { Tracing }\end{array}$ & $\begin{array}{l}\text { Cutting } \\
\text { Rough hewing } \\
\text { Facing } \\
\text { Tracing } \\
\text { Chiseling } \\
\text { Drilling } \\
\text { Joining } \\
\text { Grafting } \\
\text { Corner joining technique } \\
\text { Mortise joining technique } \\
\text { Bending } \\
\text { Lathing } \\
\text { Cutting-planing (woodcarving) }\end{array}$ \\
\hline
\end{tabular}

Fig. 1. Wood processing in the Early Iron Age in the Altai. 


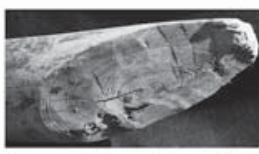

1

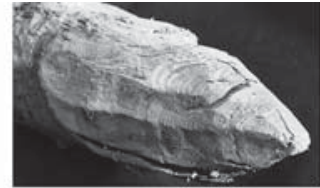

2

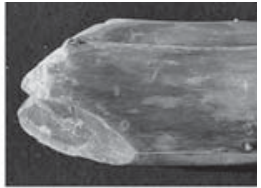

3

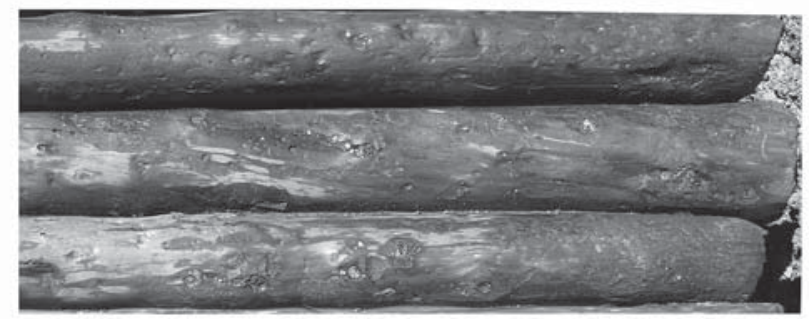

4

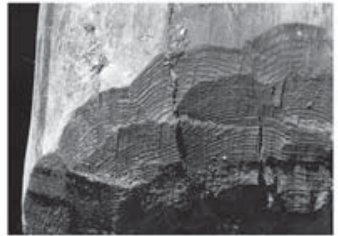

5

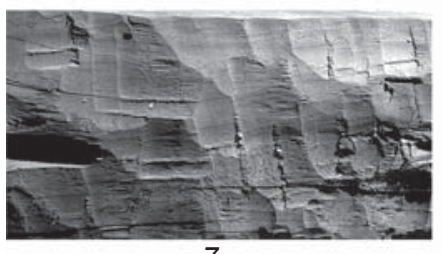

7

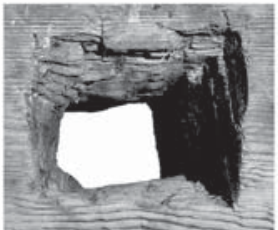

9
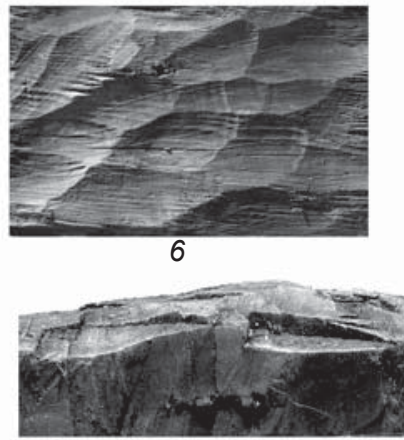

8

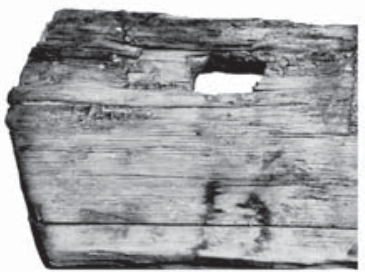

10

Fig. 2. Traces of processing with metal tools on wooden items of the Early Iron Age. Altai.

1-3 - chopping with axe; 4 - removing bark from logs with axe and adze; $5-7$ - trimming with adze; 8 - trimming with axe; 9 - cutting hole with chisel and adze; 10 - cutting hole with mortise chisel and regular chisel.

Experimental studies are very important for establishing the composition of a toolkit. In the Early Scythian kurgan of Arzhan in Tuva, traces of processing have survived on $560 \mathrm{logs}$ of the burial structure, but the tools have not been found. On the basis of results of usewear analysis of blade marks, scholars have concluded that the logs of the complex were cut using two types of tools - an axe with a blade 4.9-6.1 cm wide, and an adze with a blade $3.5-4.5 \mathrm{~cm}$ wide. Technical and technological analysis of their traces has shown that the tools were cast in no less than 72 molds (Nemirovskaya, 1975).

Experimental use-wear analysis of tools and their marks makes it possible to confirm the function of an item and its manufacturing technique, reconstruct the organization of production and technological processes, and to some extent assess the level of skills of an ancient human (Semenov, Korobkova, 1983: 3-5; Volkov, 2000; Mylnikov, 2008: 22-26; 2011: 104-114; 2014: 55-59).

When identifying the types of Early Iron Age woodworking tools from their traces, we used the following definitions: woodworking tools - a set of specialized tools for wood processing; wood processing - a system of techniques and methods for applying various tools to the surface of wood in order to change its primary shape to the intended volume and size.

Depending on skills and goals, ancient artisans, like modern craftsmen, determined the qualitative and quantitative composition of the tools needed for carrying out a particular technological task. Most likely, a blacksmith or caster made the working parts 

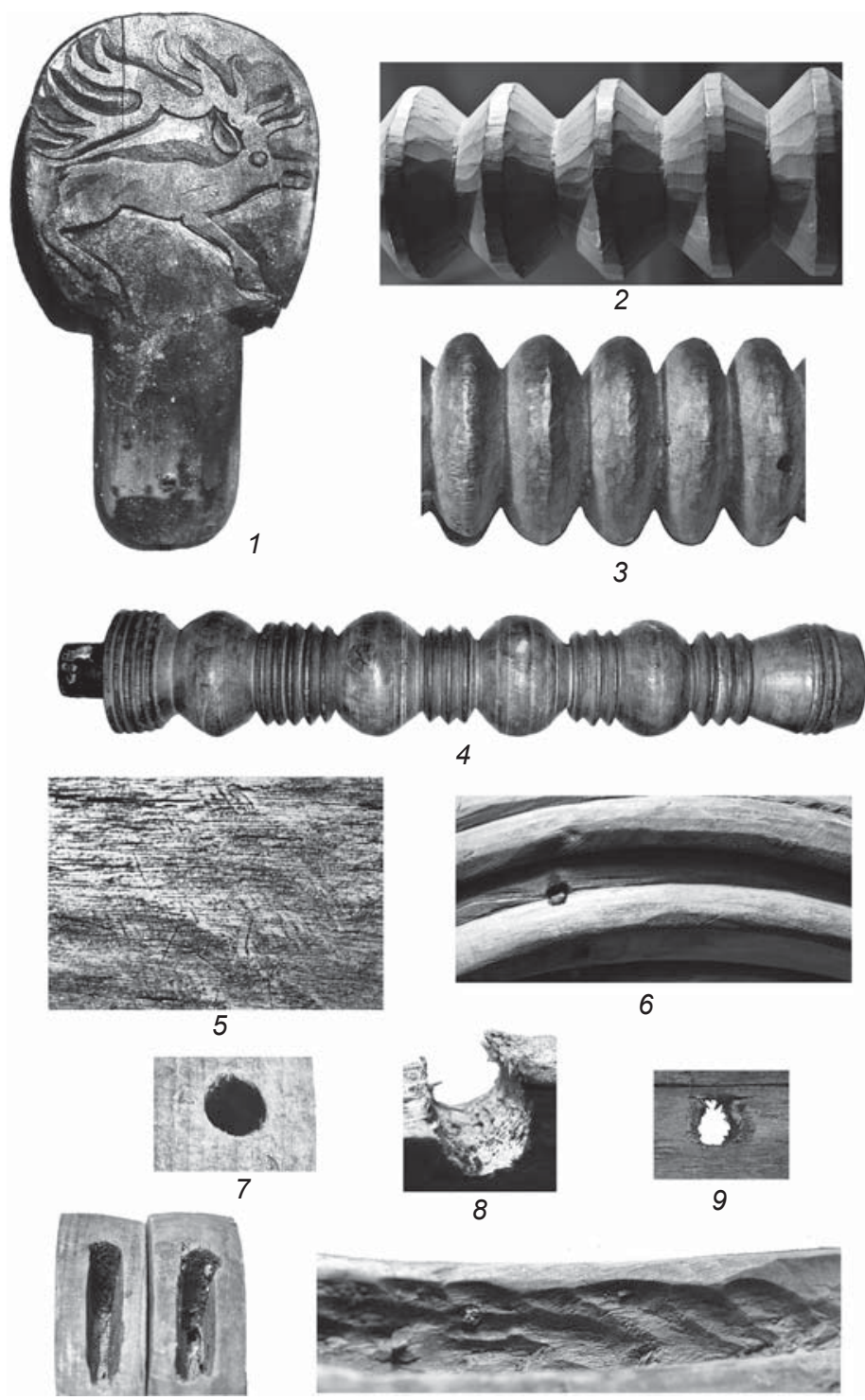

10

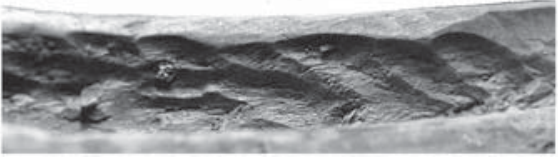

11

Fig. 3. Traces of processing with metal tools on wooden items of the Early Iron Age. Altai. 1, 2 - carving with knife; 3 - smoothing; 4 - lathing; 5 - scraping (treating with a rasp-like tool); 6 - polishing; 7,8 - drilling with bow drill (round metal rod with a bifurcated bit); 9 - drilling with awl with the bifurcated end (reamer); 10,11- recesses cut by chisels with flat and semicircular working edges.

of woodworking tools according to requests and sizes specified by the artisan (this is indicated by the variety of forms, types, and number of elements). Woodworkers carved tool handles out themselves; they adjusted handles to their own hands so it would be possible to carry out any operation as conveniently and effectively as possible. Modern "traditional craftsmen", who work with wood their entire lives, do the same (Tokunaga Kyoko, 1997; Tokunaga Kyoko, Itakura Yoshiko, 1997: 13).

Information about wood processing contained in the studies by M.P. Gryaznov (1950, 1980), S.I. Rudenko (1948, 1953, 1960, 1962), S.A. Semenov (1956, 1957), S.A. Semenov and G.F. Korobkova (1983), K.A. Akishev,
G. Kushaev (1963), A.D. Grach (1980), and E.L. Nemirovskaya (1975); the results of our own trace studies and comparative-typological analyses of wooden artifacts with marks of tools; ethnographic evidence; and experimental data suggest that carpenters of the Altai and adjacent territories in the Early Iron Age used the following types of tools for wood processing: chopping, striking, cutting tools and their varieties, piercing and boring tools, and tools of combined action.

Chopping tools - adzes, celts, and axes - consisted of wooden handle and metal part with sharp cutting blade of various widths and profiles (Fig. 4, 5). From the Upper Paleolithic to the Chalcolithic, axes and adzes were made 


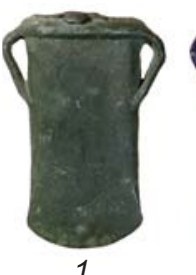

1

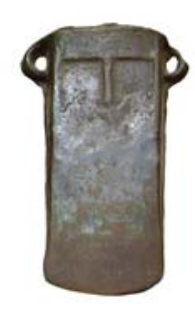

6
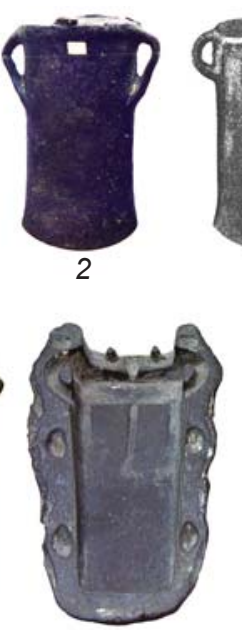

7

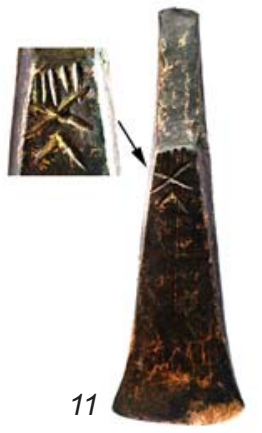

0 $5 \mathrm{~cm}$

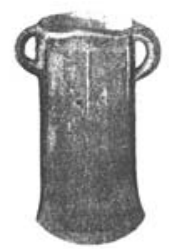

3

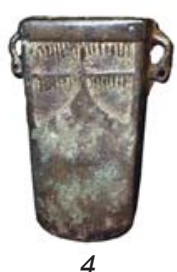

4

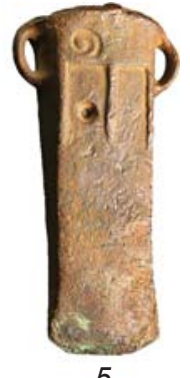

5

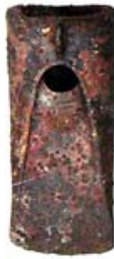

8

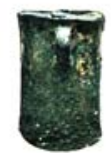

10

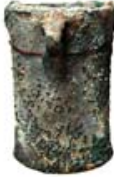

9

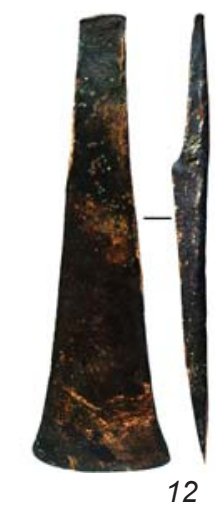

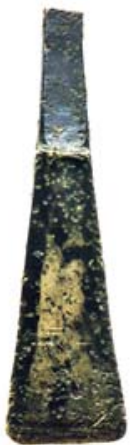

13

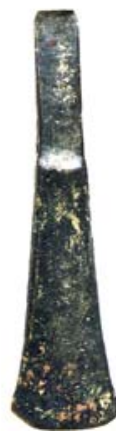

14

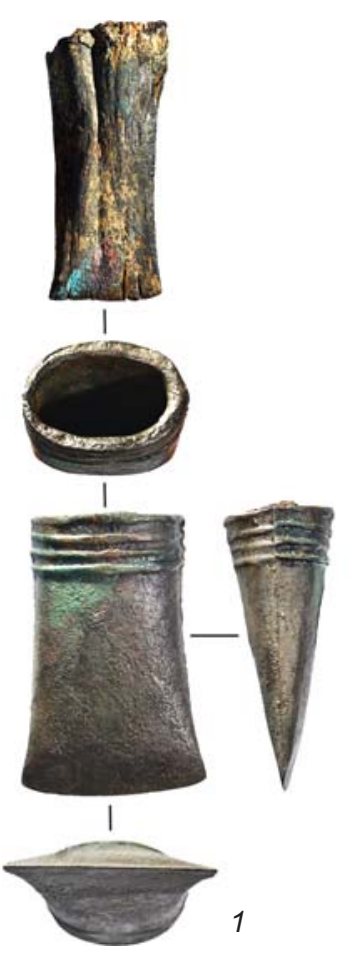

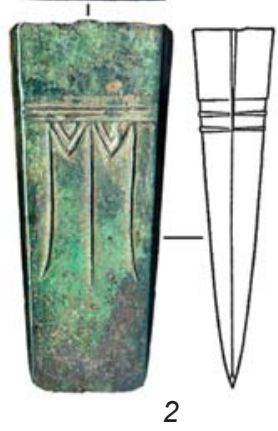

2

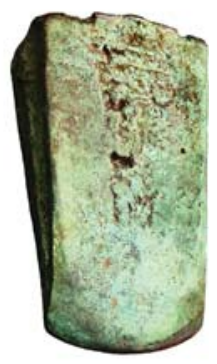

3
0 $5 \mathrm{~cm}$
Fig. 4. Double-looped celts $(1-6)$, casting mold for making celts (7), socketed celt with a hollow (8), single-looped celts $(9,10)$, flat facing adzes with tangs (11-14) of transitional period from the Bronze Age to the Iron Age, and of the Early Iron Age. Altai. 1, 2, 6-14-Museum of the Altai State University, Barnaul (Radlov, 1896); 4 - Museum of the Siberian Federal University, Krasnoyarsk; 5 - Kyzlasov Khakassia National Museum of Local History, Abakan.

of the hardest types of stone, such as flint, quartz, basalt, or jasper; subsequently, they began to be made of copper and bronze, and from the 6th5 th centuries BC primarily of iron. The iron axe was the most sophisticated tool in terms of its manufacture, and was the most universal carpenter's tool in this category (Zavyalov, 1987: 156; Kolchin, 1953: 100-110; 1985).

For a long time, the celt axe was the most common tool for wood processing (see Fig. 4, $1-10 ; 5 ; 6,8-11)$. Depending on the hafting (orientation of blade in a longitudinal or transverse direction relative to the axis of handle) and the cross-section of the blade, it could be used either as an axe (with a blade symmetrical in cross-section) or as adze (with an asymmetrical blade).

In collections of bronze cast chopping tools, multifunctional celts were identified: single- and double-looped, symmetrical and asymmetrical in cross-section, shovel-like celts, and celt-adzes with a hollow and blade of different sizes and configurations (Bekhter, Khavrin, 2002: Fig. 1, 1, 2, 10, 12, 14). Usewear analysis has shown that the sizes of marks left by celt blades on wooden items of the Early Iron Age in the Altai and adjacent territories ranged from 3.7 to $5.9 \mathrm{~cm}$. Single- and doublelooped celts were multifunctional (axe-adze); shovel-like celts and celt-adzes with a hollow were used by ancient carpenters only as adzes. Celts with semicircular back wall and concave front wall, and with semicircular or sometimes crescent blade, were used for removing a large amount of wood when making cavities during manufacturing wooden slabs and blanks for dishware production.

Adzes intended only for trimming were of different types: with oval back wall and flattened blade ("passing" adzes) — for the primary

Fig. 5. Socketed celts. Western Siberia.

1 - transitional period from the Bronze Age to the Iron Age, Museum of History and Culture of Peoples of Siberia and Russian Far East, IAET SB RAS; 2 - the Early Iron Age, Museum of the Siberian Federal University, Krasnoyarsk; 3 - the Early Iron Age, Kyzlasov Khakassia National Museum of Local History, Abakan. 
1

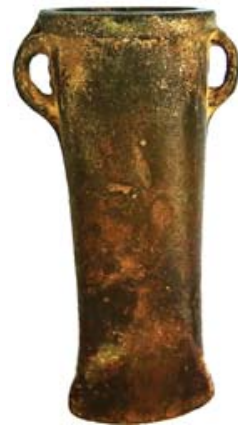

8

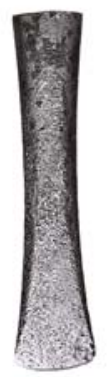

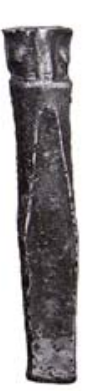

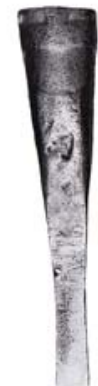

3

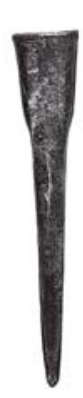

4

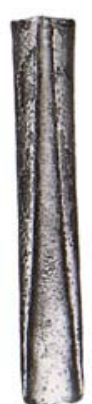

5

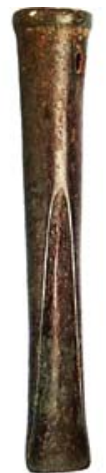

6

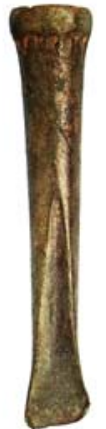

7

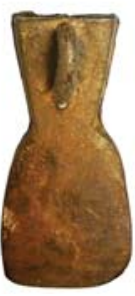

9
0

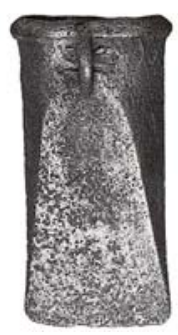

10

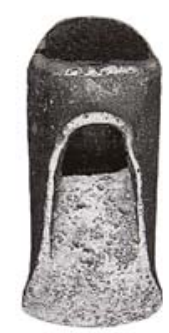

11
With the development of iron processing skills and techniques in the 3rd century $\mathrm{BC}$ to the 2 nd century $\mathrm{AD}$, bronze single- and double-looped celts completely disappeared (Chernetsov, 1954: 186). They were replaced by more convenient and efficient tools with open sockets (Soenov, Konstantinova, 2013), as well as shaft-hole adzes and axes made of iron and steel. For dividing large logs into planks (by splitting), wedge-shaped axes were used, looking similar to the present-day splitting axes, with a symmetrical or asymmetrical body in the cross-section. For specialized carpentry, hammer axes were invented, which performed the functions of two tools - axe and hammer (Frolov, 1996; Kiryushin, Ivanov, 1996; Abdulganeev, 1996: 132; Nelin, 1996; Ivanov, Isaev, 1999).

Bronze celts with the body asymmetrical in crosssection, shovel-like celts, and celt-adzes with a hollow were transformed into classic shaft-hole tools: removing, passing, and facing adzes with iron or steel blades of various shapes and sizes. Axes and adzes are also the main tools among modern carpenters.

Striking tools-hammers, mallets of different sizes made of wood, mauls of wood and horn with handles. Ancient carpenters used these as intermediate tools for working with chisels, for fitting the elements of corner joints, etc.

Fig. 6. Mortise chisels, chisels (1-7), doublelooped celt $(8)$, single-looped celts $(9,10)$, and celt with a hollow (11) from hoards of the transitional period from the Bronze Age to the Iron Age, 12th-9th centuries BC. Kazakhstan. 1-5, 10, 11 - (Popescu, Antonini, Baipakov, 1998: 262, fig. 389, 396); 6, 7 - (Ibid.: 123, fig. 48, 49); 8 - (Ibid.: 184, fig. 50); 9 -(Ibid.: 184, fig. 51).

processing of large planes with a large area of timber, and with a straight back and front walls, and a flat even blade ("facing" adzes) for treating small areas of timber during final evening and facing of commercial-timber planes during construction and creation of blanks for manufacturing various small wooden household items, as well as for carving (see Fig. 4, 11-14; 6, 8-11). The sizes of marks left by the blades of flat tanged adzes were $3.7 \times 4.9 \mathrm{~cm}$.

Fig. 7. Chisels (1-5), knives (6-9), and awls (10-14) from archaeological sites of the Early Iron Age of the Altai, Western Siberia, and Kazakhstan.

1-4, 12-14 - Museum of the Altai State University, Barnaul; 5 - Museum of the village of Novoselovo, Krasnoyarsk Territory; 6-11 - (Bolshoy atlas Kazakhstana, 2011: 363, 364).

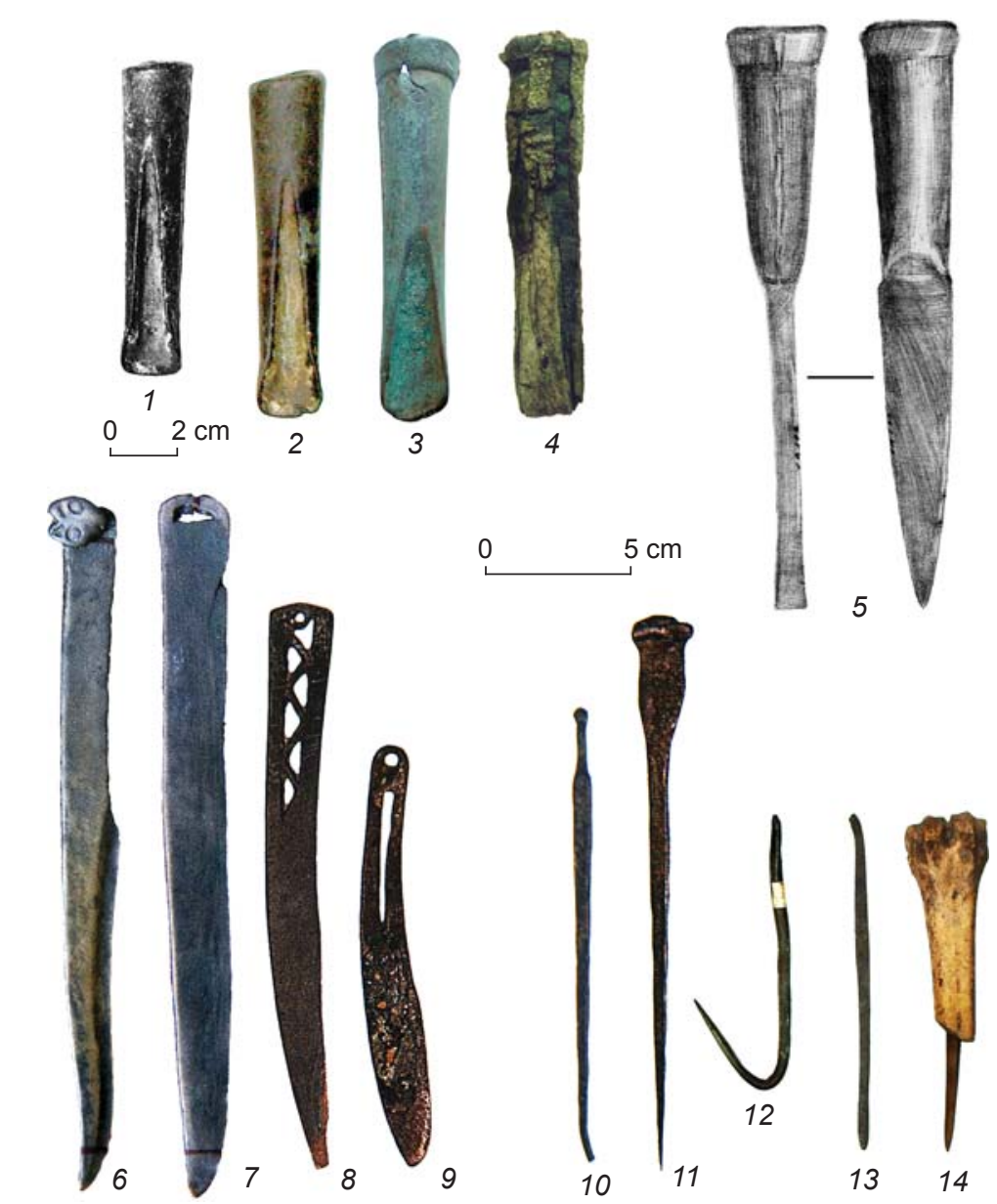


Combined tools (striking and cutting, driven by striking tools) - mainly metal mortise chisels (made of bronze or iron) and rarely chisels. These were used for hollowing during production of through and deaf apertures (Mylnikov, 2003), for connecting individual parts of wood and other materials (see Fig. 6, 1-7; 7, 1-5). The sizes of chisels' working surfaces were $9 \times 25 \mathrm{~mm}$.

Cutting tools - lathing burins made of hardened iron or steel (Ibid.). These were used for manufacturing elements of sophisticated profile-stalks for wooden dishes, legs and backs of chairs, and decorations for the wooden chariots of nobles.

Cutting and boring tools - flat drills (made of bronze and iron) with manual and bow drives, reamers (rods with the bifurcated working part, with pointed edges). These were used to drill through and blind holes of various diameters and depths, in manufacturing a wide range of household and weaponry items.

Universal cutting and shaving tools - bronze and iron knives of various shapes, medium-sized and smallsized, most often with a narrow back and a very sharp thin blade (see Fig. 7, 6-9; 8, 1-15), small chisels with a semicircular or flat blade (see Fig. 6, 1-7), and mortise chisels with a wide flat blade. These were used to prepare the surface by facing the blanks for all types of carving, making recesses, in manufacturing dishware, etc.

Piercing and boring tools - awls - thin long round rods of various diameters, pointed at one end, made of bronze or iron, with wooden handles (see Fig. 7, 10-14). These were used not only for piercing various holes and recesses, but also for marking patterns and profiles on wooden blanks as a drawing or marking tool.

The results of use-wear analysis indicate that as early as the Early Bronze Age in the Altai, craftsmen were skilled at fashioning three types of processing wooden surfaces with chopping tools: butting, cutting with the grain, and cutting across the grain. During experiments, some peculiarities of working with large-sized timber have been identified, which are confirmed by the ethnographic evidence.

The effectiveness of wood processing depends on the sharpness angle of the blade, the inclination angle of the
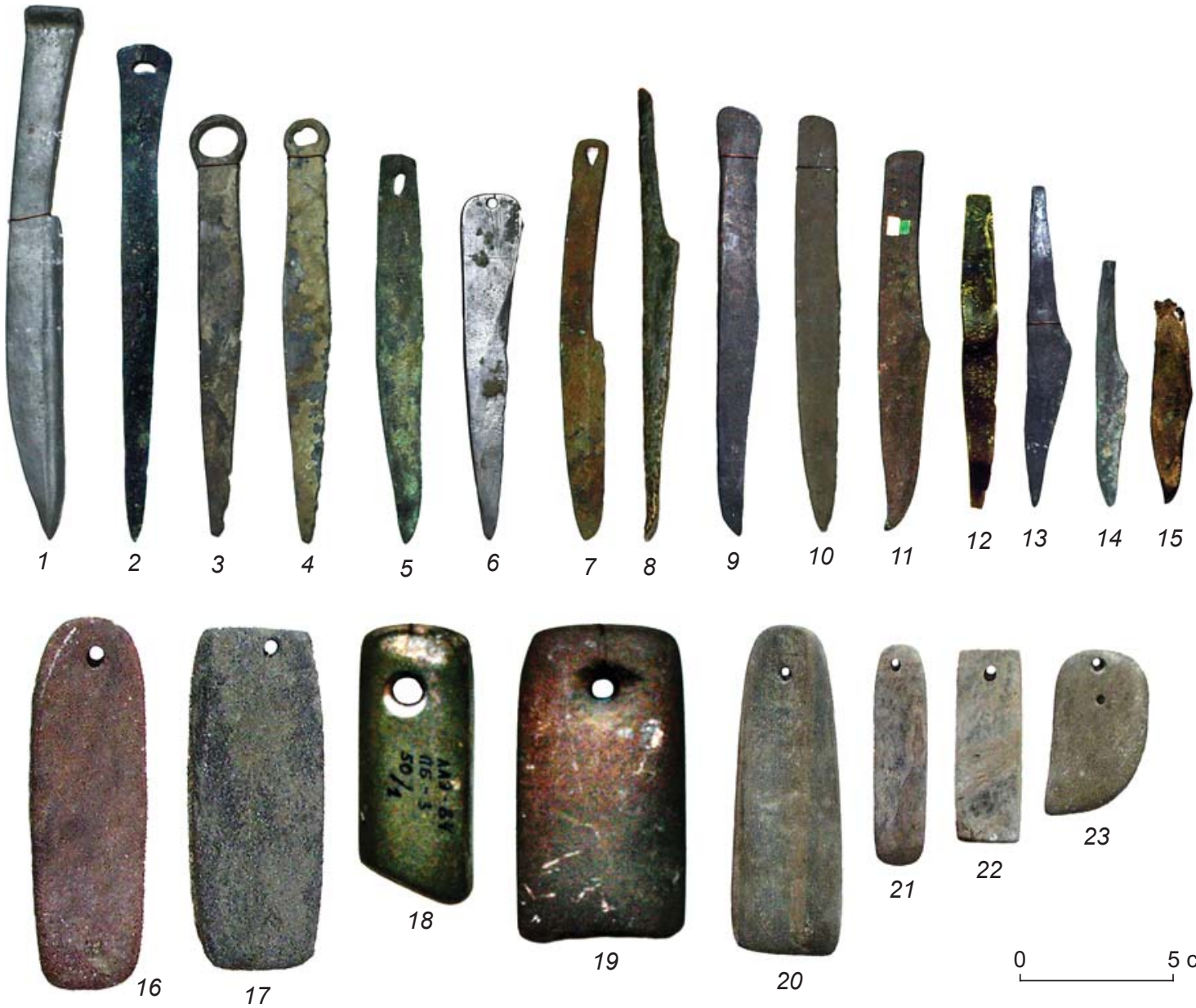

Fig 8. Knives (1-15) and stone abrasive tools (16-23) of the Early Iron Age from the Altai and Kazakhstan. 1-15 - Museum of the Altai State University, Barnaul; 16-23 - Museum of the Margulan Institute of Archaeology, Almaty, Kazakhstan. 
blade relative to the supporting handle, the chopping angle, as well as the angle of trimming or cutting the wood (that is, the inclination angle of the tool during its operation), the direction of chopping, trimming, or cutting the surface (the height and angle of inclination of the artisan), the width of the working edge of the blade, the shape of the working edge of the blade (oval, semicircular, or flattened), the degree of the bluntness on a tool's blade, the friction of the blade against the timber (shavings), as well as the hardness and elasticity of the timber.

The surface finish of wood is determined by the shape, integrity (preservation), and sharpness of the working edge on the blade of a metal tool; the depth and angle of wood chopping, trimming, or cutting; the amount of applied physical power; the pliability, and the degree of wood desiccation or moisture content.

It was necessary to choose the right abrasive tool for optimal sharpening and straightening of the blades during work, which would ensure a quality treatment of the wood surface. Sharpeners and whetstones were most often elongated rectangular or sub-trapezoidal flattened bars of gray or brown sandstone, mudstone, or steatite. According to the degree of granularity, they were divided into coarse, medium, and fine (Lukas, 1958: 670-680; Theophrastus, 1951: 178). Whole sets of abrasive tools of various sizes and configurations have been found in the burials of the Early Iron Age (see Fig. 8, 16-23). Whetstones were flat in cross-section and had rounded ends. In the 6th5 th centuries $\mathrm{BC}$, the most valuable abrasives could have been used as symbols of power-wands. They were set in golden hilt-cases decorated with granulation. Given that whetstones have often been found among the inventory, it was previously suggested that they might have been used as amulets (Gryaznov, 1961). However, according to ethnographic research, whetstones served not only as grindstones, but also as a means for healing wounds (Korolkova, 2001: 72, collection 8; Galanina, 2001: 200, collection 177).

When determining the main stages of wood processing, we have taken into account the principle developed by many generations of woodworking specialists: for each specific operation, a tool was primarily used that was specifically designed for that operation. It is possible that in some cases the high degree of skill of individual artisans allowed them to perform several sequential operations with a single tool. For example, construction and house-building among the Ob Ugrians determined the rational composition of the toolkit, certain types of which (axe, adze, chisel, and knife) had been multifunctional since ancient times (Morozov, 1993: 198-199). Using the axe, the present-day carpenters can first cut (fall) the tree, then clear the trunk from the branches, remove the bark, cut the trunk into logs, trim the logs, and split them into planks, using the metal working part of the axe as a wedge; pick with the axe and not with the chisel (the rough cutting of large holes has been known since ancient times) (Semenov, 1956: 210), and even plane small planks, sticks, and pegs.

A comprehensive analysis of a significant number of primary sources with a good degree of preservation, showing numerous traces of blades left by various tools, and the comparative analysis of secondary sources suggest that there were three main branches of woodworking in the Altai in the Early Iron Age: construction, carpentry, and woodcarving. Numerous burial structures made of wood (structures above the cribworks, cribworks, burial beds, etc.), which reflect rich practices for building dwellings and household structures, as well as various small wooden items for household needs, weaponry, and decorations, indicate the use of a variety of specialized tools employed by the artisans for each of the woodworking branches.

\section{Conclusions}

Tools for working with timber were one of the main components for woodworking in ancient times. The problem of distinguishing tools for wood processing in the Early Iron Age in the Altai, their identification, attribution, and classification is caused by the fact that woodworking tools, with rare exceptions, have not been found at the archaeological sites associated with a specific culture. Their parallels have been found in surface materials and hoards, and appear among random finds.

To establish the external appearance of tools, reconstruct techniques and methods of working with them, and identify special sets of woodworking tools, one needs to carry out a number of special studies of original sources-wooden items of that time with traces of processing.

Use-wear analysis of processing marks surviving on the internal and external surfaces of wooden items, a comparative typological analysis of indirect sources (metal tools) from the archaeological sites of close chronological periods, random finds and hoards, as well as experimental data from working with replicas of these tools, all serve as a basis for reconstructing each stage and operation of wood processing and the manufacturing of artifact, and hence, for restoring the entire process of woodworking and creating a finished product with the maximum degree of conformity to the prototype.

\section{References}

\section{Abdulganeev M.T. 1996}

"Neizvestniye" pamyatniki rannego zheleznogo veka $\mathrm{v}$ severnykh predgoryakh Altaya. In Sokhraneniye i izucheniye kulturnogo naslediya Altaiskogo kraya: Materialy nauch.praktich. konf. Barnaul: pp. 128-134. 
Akishev A.K. 1984

Iskusstvo i mifologiya sakov. Alma-Ata: Nauka KazSSR.

Akishev K.A., Kushaev G.A. 1963

Drevnyaya kultura sakov i usuney doliny reki Ili. Alma-Ata: Izd. AN KazSSR.

Bekhter A.V., Khavrin S.V. 2002

Stepniye bronzy iz provintsii Gansu i Sintszyan-Uygurskogo avtonomnogo rayona Kitaya i problemy vostochnoy linii sinkhronizatsii. In Tsentralnaya Aziya i Pribaikalye $v$ drevnosti. Ulan-Ude, Chita: Izd. Buryat. Gos. Univ., pp. 73-78.

Bolshoy atlas Kazakhstana. 2011

Moscow: Dizain. Informatsiya. Kartografiya, Feoriya.

Borisov I.B. 1999

Obrabotka dereva. Rostov-on-Don: Feniks.

Chernetsov V.N. 1954

Review of Rudenko S.I. Kultura naseleniya Gornogo Altaya v skifskoye vremya. In Sovetskaya etnografiya, No. 2. Moscow, Leningrad: Izd. AN SSSR, pp. 183-187.

Chernykh E.N. 1972

Metall - chelovek - vremya. Moscow: Nauka.

Frolov Y.V. 1996

Noviye sluchainiye nakhodki predmetov vooruzheniya iz Vostochnogo Kazakhstana. In Sokhraneniye i izucheniye kulturnogo naslediya Altaiskogo kraya: Materialy nauch.-prakt. konf. Barnaul: pp. 91-94.

Galanina L.K. 2001

Skifskoye iskusstvo Severnogo Prichernomorya. In Zolotiye oleni Yevrazii. St. Petersburg: Izd. Gos. Ermitazha, pp. 164-203.

Grach A.D. 1980

Drevniye kochevniki v tsentre Azii. Moscow: Nauka.

Gryaznov M.P. 1950

Perviy Pazyrykskiy kurgan. Leningrad: Izd. Gos. Ermitazha.

Gryaznov M.P. 1961

Tak nazyvayemiye oselki skifo-sarmatskogo vremeni. In Issledovaniya po arkheologii SSSR. Leningrad: Leningr. Gos. Univ., pp. 139-144.

Gryaznov M.P. 1980

Arzhan. Leningrad: Nauka.

Ivanov G.E., Isaev N.N. 1999

Bronzoviy topor s poseleniya Krestyanskoye IV. In Sokhraneniye i izucheniye kulturnogo naslediya Altaiskogo kraya: Materialy Vseros. nauch.-prakt. konf., iss. X. Barnaul: pp. 82-85.

Kiryushin Y.F., Ivanov G.E. 1996

Noviye nakhodki metallicheskikh izdeliy iz Shipunovskogo rayona. In Sokhraneniye i izucheniye kulturnogo naslediya Altaiskogo kraya: Materialy nauch.-prakt. konf. Barnaul: pp. 81-91.

\section{Kolchin B.A. 1953}

Chernaya metallurgiya i metalloobrabotka v Drevney Rusi (Domongolskiy period). Moscow: AN SSSR. (MIA; No. 32).

Kolchin B.A. 1985

Remeslo. Drevnyaya Rus: Gorod, zamok, selo. Moscow: Nauka, pp. 243-297.

\section{Korolkova E.F. 2001}

Filippovskiye kurgany i zveriniy stil. In Zolotiye oleni Yevrazii. St. Petersburg: Izd. Gos. Ermitazha, pp. 64-163.

Lukas A. 1958

Materialy i remeslenniye proizvodstva Drevnego Egipta. Moscow: Inostr. lit.

\section{Morgunova N.L. 1994}

$\mathrm{K}$ voprosu ob istokakh sarmatskogo elitarnogo pogrebalnogo obryada (Po materialam epokhi bronzy Yuzhnogo Priuralya). In Elitniye kurgany stepey Yevrazii v skifo-sarmatskuyu epokhu: Materialy zasedaniy "kruglogo stola" (22-24 dekabrya 1994 g.). St. Petersburg: IIMK RAN: Gos. Ermitazha, pp. 166-169.

\section{Morozov V.M. 1993}

Domostroyeniye u obskikh ugrov (po dannym razlichnykh istochnikov). In Znaniya $i$ navyki uralskogo naseleniya $v$ drevnosti i srednevekovye. Yekaterinburg: Nauka, pp. 192-203.

Mylnikov V.P. 1999

Obrabotka dereva nositelyami pazyrykskoy kultury. Novosibirsk: Izd. IAET SO RAN.

\section{Mylnikov V.P. 2003}

Derevyanniye pogrebalniye sooruzheniya epokhi bronzy Zapadnoy Sibiri. In Sotsialno-demograficheskiye protsessy na territorii Zapadnoy Sibiri (drevnost i srednevekovye). Kemerovo: Izd. Kem. Gos. Univ., pp. 151-154.

\section{Mylnikov V.P. 2008}

Derevoobrabotka v epokhu paleometalla (Severnaya i Tsentralnaya Aziya). Novosibirsk: Izd. IAET SO RAN.

Mylnikov V.P. 2011

Rezba po derevu v skifskoye vremya (Severnaya Aziya). Novosibirsk: Izd. IAET SO RAN.

\section{Mylnikov V.P. 2014}

Izucheniye arkheologicheskikh derevyannykh predmetov (pogrebalniye pamyatniki Altaya i sopredelnykh territoriy). Moscow: IA RAN. (Metodika polevykh arkheologicheskikh issledovaniy; iss. 8).

\section{Mylnikov V.P., Bobrov V.V. 2011}

Derevyanniye pogrebalniye sooruzheniya epokhi bronzy Zapadnoy Sibiri. Vestnik Novosibirskogo Gosudarstvennogo Universiteta, vol. 10, iss. 3: Arkheologiya i etnografiya: 92-99.

\section{Nelin D.V. 1996}

Topory epokhi bronzy iz fondov Chelyabinskogo oblastnogo krayevedcheskogo muzeya. In Materialy po arkheologii $i$ etnografii Yuzhnogo Urala. Chelyabinsk: Tvorch. obyed. "Kamenniyi poyas", pp. 183-187. (Tr. muzeya-zapovednika Arkaim).

\section{Nemirovskaya E.L. 1975}

Obrabotka dereva stroitelyami kurgana Arzhan. In Ucheniye zapiski TNIIYALI, vol. 17. Kyzyl: pp. 207-211.

Popescu G.A., Antonini C.S., Baipakov K. 1998

L'uomo d'oro. La cultura delle steppe del Kasakhstan dall'età del bronzo alle grandi migrazioni. Venezia: Electa.

\section{Radlov V.V. 1896}

Sibirskiye drevnosti: Iz putevykh zapisok po Sibiri, A.A. Bobrinskiy (trans. from German). St. Petersburg: [Tip. I.N. Skorokhodova].

\section{Raev B.A. 1976}

Tekhnika fiksatsii sledov drevnikh orudiy s pomoshchyu gipsovykh slepkov. Sovetskaya arkheologiya, No. 4: 213-215.

\section{Rudenko S.I. 1948}

Vtoroy Pazyrykskiy kurgan. Leningrad: Izd. Gos. Ermitazha. Rudenko S.I. 1953

Kultura naseleniya Gornogo Altaya v skifskoye vremya. Moscow, Leningrad: Izd. AN SSSR.

\section{Rudenko S.I. 1960}

Kultura naseleniya Tsentralnogo Altaya v skifskoye vremya. Moscow, Leningrad: Izd. AN SSSR. 


\section{Rudenko S.I. 1962}

Kultura khunnov i Noinulinskiye kurgany. Moscow, Leningrad: Izd. AN SSSR.

Semenov S.A. 1956

Obrabotka dereva na drevnem Altaye. Sovetskaya arkheologiya, vol. XXVI: 204-230.

Semenov S.A. 1957

Pervobytnaya tekhnika. Moscow, Leningrad: Nauka. (MIA; No. 54).

\section{Semenov S.A., Korobkova G.F. 1983}

Tekhnologiya drevneishikh proizvodstv. Mezolit - neolit. Leningrad: Nauka.

Soenov V.I., Konstantinova E.A. 2013

Derevoobrabatyvayushchiye instrumenty iz mogilnika Verkh-Uymon (Altay). In Teoriya i praktika arkheologicheskikh issledovaniy, No. 2. Barnaul: Izd. Alt. Gos. Univ., pp. 42-57.

Theophrastus. 1951

Enquiry into Plants. Transl. from Classical Greek. Leningrad: Izd. AN SSSR.

Tokunaga Kyoko. 1997

Traditsionnyi drovosek. NIPPONIA. Discovering Japan, No. 1: 9.
Tokunaga Kyoko, Itakura Yoshiko. 1997

Mastera po derevu. NIPPONIA. Discovering Japan, No. 1: 10-13.

Usacheva I.V. 1997

Kompleks kamennykh derevoobrabatyvayushchikh orudiy epokhi neolita. In Uralskiy istoricheskiy vestnik, No. 4. Yekaterinburg: pp. 118-124.

Volkov P.V. 2000

New aspects of research in experimental Paleolithic archaeology. Archaeology, Ethnology and Anthropology of Eurasia, No. 4: 30-37.

Zavyalov V.I. 1987

Derevoobrabatyvayushchiy instrumentariy prikamskikh plemen. In Noviye arkheologicheskiye issledovaniya na territorii Urala. Izhevsk: Izd. Ur. Gos. Univ., pp. 156-161. 